\title{
Remotely induced warming of Antarctic Bottom Water in the eastern Weddell gyre
}

\author{
Matthew P. Couldrey, ${ }^{1}$ Loïc Jullion, ${ }^{1,2}$ Alberto C. Naveira Garabato, ${ }^{1}$ Craig Rye, ${ }^{1}$ \\ Laura Herráiz-Borreguero, ${ }^{3}$ Peter J. Brown, ${ }^{4,5}$ Michael P. Meredith, ${ }^{5,6}$ and Kevin L. Speer ${ }^{7}$ \\ Received 28 February 2013; revised 28 April 2013; accepted 29 April 2013; published 10 June 2013.
}

[1] Four repeat hydrographic sections across the eastern Weddell gyre at $30^{\circ} \mathrm{E}$ reveal a warming (by $\sim 0.1^{\circ} \mathrm{C}$ ) and lightening (by $\sim 0.02-0.03 \mathrm{~kg} \mathrm{~m}^{-3}$ ) of the Antarctic Bottom Water (AABW) entering the gyre from the Indian sector of the Southern Ocean between the mid-1990s and late 2000s. Historical hydrographic and altimetric measurements in the region suggest that the most likely explanation for the change is increased entrainment of warmer mid-depth Circumpolar Deep Water by cascading shelf water plumes close to Cape Darnley, where the Indian-sourced AABW entering the Weddell gyre from the east is ventilated. This change in entrainment is associated with a concurrent southward shift of the Antarctic Circumpolar Current's (ACC) southern boundary in the region. This mechanism of AABW warming may affect wherever the ACC flows close to Antarctica. Citation: Couldrey, M. P., L. Jullion, A. C. Naveira Garabato, C. Rye, L. Herráiz-Borreguero, P. J. Brown, M. P. Meredith, and K. L. Speer (2013), Remotely induced warming of Antarctic Bottom Water in the eastern Weddell gyre, Geophys. Res. Lett., 40, 2755-2760, doi:10.1002/grl.50526.

\section{Introduction}

[2] The meridional overturning circulation is a key mechanism by which the ocean transports heat, carbon, and other climatically important tracers around the planet [e.g., Ganachaud and Wunsch, 2000]. Production of dense bottom water (collectively named Antarctic Bottom Water, AABW) at a few specific high-latitude regions of the Southern Ocean constitutes an important part of this circulation. AABW formation is driven by seawater density modification through air-sea-ice interactions near the Antarctic margins [Orsi et al., 1999] that are sensitive to climatic forcing.

\footnotetext{
${ }^{1}$ University of Southampton, National Oceanography Centre, Southampton, UK.

${ }^{2}$ Now at Geophysical Fluid Dynamics Institute, Florida State University, Tallahassee, Florida, USA

${ }^{3}$ Antarctic Ecosystems and Climate Cooperative Research Centre, University of Tasmania, Hobart, Tasmania, Australia. UK.

${ }^{4}$ School of Environmental Sciences, University of East Anglia, Norwich,

${ }^{5}$ British Antarctic Survey, Cambridge, UK

${ }^{6}$ Scottish Association for Marine Science, Oban, UK.

${ }^{7}$ Department of Earth, Ocean and Atmospheric Science, Florida State University, Tallahassee, Florida, USA.

Corresponding author: M. P. Couldrey, University of Southampton, National Oceanography Centre, Southampton, SO14 3ZH, UK. (couldrey. matthew@gmail.com)

(C2013. American Geophysical Union. All Rights Reserved. 0094-8276/13/10.1002/grl.50526
}

[3] AABW has experienced pronounced property changes in recent decades. Purkey and Johnson [2010, 2012] report widespread warming and volumetric contraction of AABW across much of the global ocean abyss since the 1980s. AABW formed in the Ross Sea and off Adélie Land freshened by, respectively, $\sim 0.01$ between the late 1960 s and the 1990s [Jacobs et al., 2002; Rintoul, 2007; Jacobs and Giulivi, 2010] and $\sim 0.03$ between the mid-1990s and the mid-2000s [Aoki et al., 2005; Rintoul, 2007]. This has been tentatively linked to shelf water freshening [Jacobs et al., 2002; Jacobs and Giulivi, 2010], possibly resulting from the accelerated mass loss of the West Antarctic Ice Sheet by enhanced basal melting [Pritchard et al., 2012].

[4] Here we expand upon the evidence for climatic changes in AABW properties by documenting a remotely induced warming of the AABW entering the Weddell gyre from the Indian sector of the Southern Ocean. Exploring the likely mechanisms for this change, we find that a southward migration of the ACC's southern boundary off the Cape Darnley/Prydz Bay region may have brought relatively warm mid-depth waters closer to the continental shelf edge, where they are entrained by cascading dense shelf water.

\section{Data Sets and Methods}

[5] Four repeats (1993, 1996, 2006, and 2008) of conductivity-temperature-depth (CTD) profiles along section I6S at $30^{\circ} \mathrm{E}$ between $61.5^{\circ} \mathrm{S}$ and $68^{\circ} \mathrm{S}$ (Figure 1) collected during the World Ocean Circulation Experiment and CLIVAR (Climate Variability and Predictability) programs were obtained via the CLIVAR and Carbon Hydrographic Data Office (http://cchdo.ucsd.edu). Additional hydrographic data and Argo float profiles were obtained from the Southern Ocean (http://woceatlas.tamu.edu/Sites/html/atlas/ SOA_DATABASE.html) and Argo database (ftp://ftp. ifremer.fr/ifremer/argo), respectively. Neutral density $\left(\gamma^{n}\right.$, $\mathrm{kg} \mathrm{m}^{-3}$ ) and dynamic height (dyn $\mathrm{m}$ ) were derived. We define AABW as water with $\gamma^{n}>28.27$, after Orsi et al. [1999]. For display, salinity $(S)$ data from 1993 and 1996 were vertically smoothed with a 20 dbar running mean.

[6] Weekly satellite snapshot sea surface height (SSH) maps (from TOPEX/Poseidon, Jason 1 and 2, ERS-1 and -2, Envisat, GFO) were obtained for the eastern Weddell gyre region $\left(55^{\circ} \mathrm{S}-65^{\circ} \mathrm{S}, 30^{\circ} \mathrm{E}-90^{\circ} \mathrm{E}\right)$ from Archiving, Validation, and Interpretation of Satellite Oceanographic Data [Le Traon et al., 1998]. Inter- and multiannual SSH changes were quantified using a least squares linear regression for sea ice-free months (January-May) from 1996 to 2008.

[7] CFC-11 and CFC-12 concentrations were analyzed for the 1993, 1996, and 2008 transects and used to calculate transit ages [after Klatt et al., 2002]. A transit time distribution 


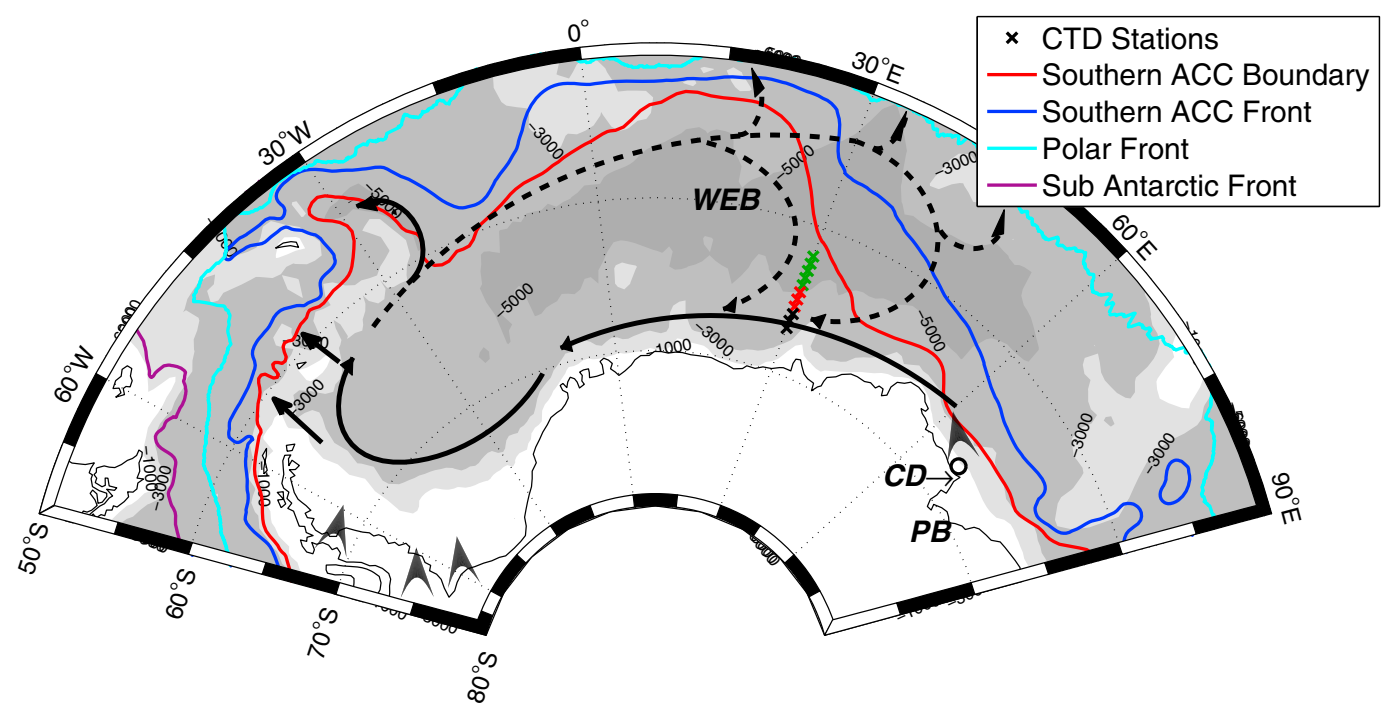

Figure 1. Schematic Weddell gyre bottom water circulation. Markers (X): hydrographic stations showing older, (green) Weddell gyre interior AABW, Weddell gyre bottom waters with a (red) weaker or (black) stronger recently ventilated eastern-sourced component (for 2008; locations and groupings were similar each year). Colored lines: meridional frontal extents [Orsi et al., 1995]. Solid arrows: well constrained flows, dashed: loosely constrained flows, unstemmed arrowheads: newly formed bottom water input. Black open circle: Cape Darnley Bottom Water formation site [Ohshima et al., 2013]. Notable locations: WEB (Weddell-Enderby Basin), CD (Cape Darnley), PB (Prydz Bay), adapted from Fahrbach et al. [2011].

(TTD) analysis of the section CFC core elicited information about advection (as transit times, the time for an atmospheric perturbation to be transmitted from the ventilated surface to an ocean interior location) and mixing (as age distributions and source water fractions). Transit ages were optimized through a least squares residual minimization between observed and calculated concentrations across a range of age dispersion values (which describe the advection $(\Gamma)$ /mixing a) 1993

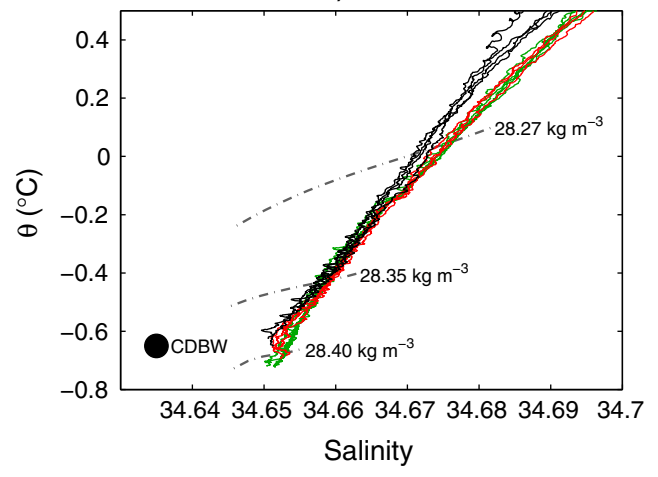

c) 2006

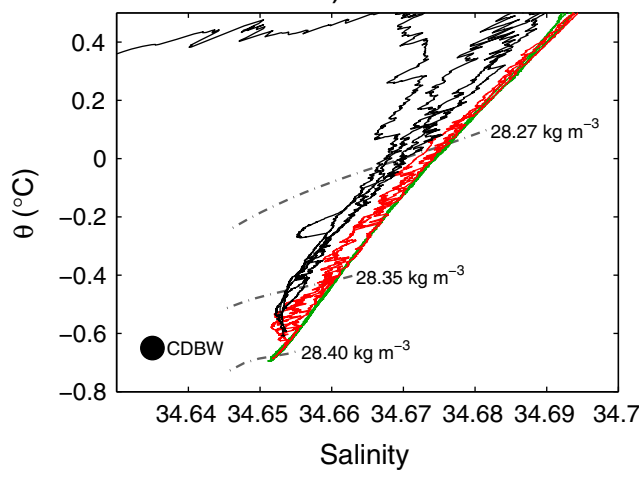

b) 1996

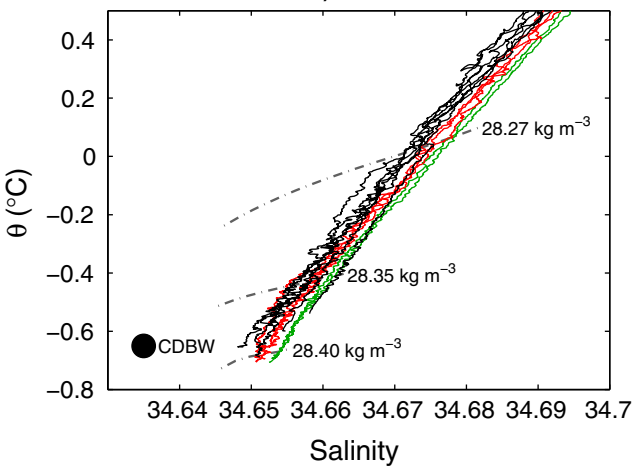

d) 2008

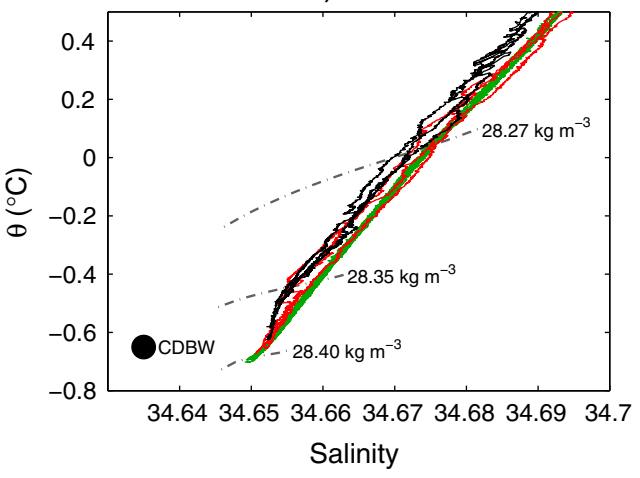

Figure 2. Potential temperature-salinity profiles along $30^{\circ} \mathrm{E}$ between $61.5^{\circ} \mathrm{S}$ and $68^{\circ} \mathrm{S}$ in (a) 1993 , (b) 1996 , (c) 2006 , and (d) 2008, colors as in Figure 1. Dashed gray lines: $\gamma^{n}$ contours. Black circle: mean Cape Darnley Bottom Water properties, from [Ohshima et al., 2013]. 

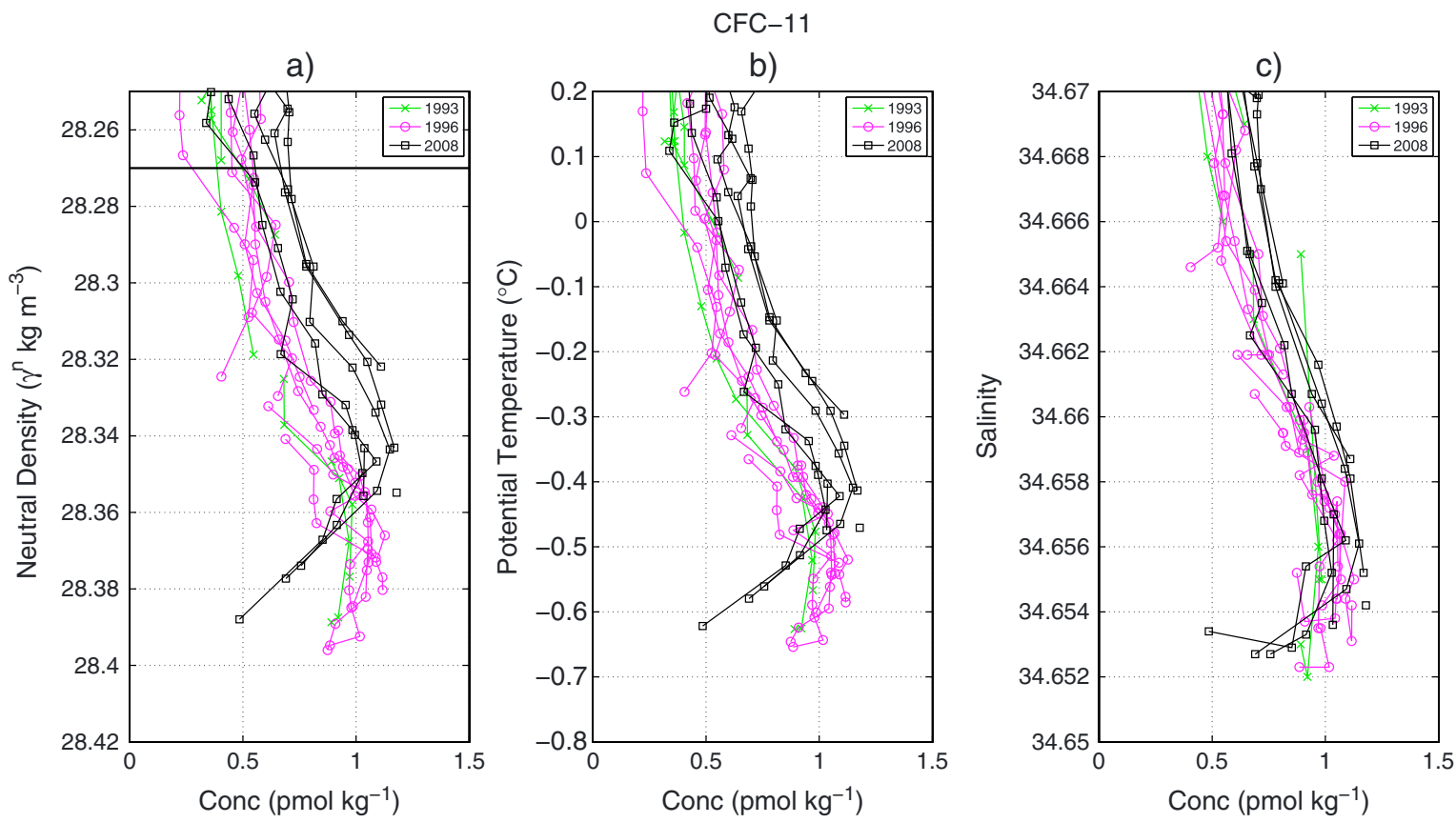

Figure 3. Profiles of CFC-11 concentration against (a) $\gamma^{n}$ (solid black bar at $\gamma^{n}=28.27 \mathrm{~kg} \mathrm{~m}^{-3}$ ), (b) potential temperature, and (c) salinity from 1993, 1996, and 2008, corresponding to black traces in Figure 2.

(4) relationship) [after Waugh et al., 2003]. An age dispersion of 2 years (signifying a relatively advective core) was used, but results were similar for values between 1 and 8 .

\section{Results}

[8] AABW properties between $61.5^{\circ} \mathrm{S}$ and $68^{\circ} \mathrm{S}$ along $30^{\circ} \mathrm{E}$ exhibit significant spatiotemporal variability. Similar profiles were grouped empirically (Figure 2) by the (green) absence or presence of a (black) stronger or (red) weaker deep CFC maximum and distinct $\theta-S$ characteristics. Latitudinal extents of the groups varied by less than $1.5^{\circ}$ between surveys. In 1993 and 1996, $\theta-S$ properties are homogeneous (Figures 2a and 2b) and AABW exhibits a deep CFC maximum at $\gamma^{n} \sim 28.37$ (Figure 3a), suggesting recent ventilation, as noted by Archambeau et al. [1998]. However, in 2006 and 2008 (Figures $2 \mathrm{c}$ and 2d), in addition to the first AABW type present at the northernmost stations (Figure 2, green), another is found farther south near the shelf break, with lower salinity (Figure 2, black), a larger $\theta-S$ spread, and a lighter CFC maximum $\left(\gamma^{n} \sim 28.34\right.$, Figure 3a). The $\gamma^{n}$ shift of the black group's CFC maxima between the 1990s and 2000s corresponds to lightening of about $0.02-0.03 \mathrm{~kg} \mathrm{~m}^{-3}$. Further, the black profiles inflect toward the green at $\gamma^{n}=28.36$ in 2006 and 2008 (Figures 2c and 2d), and show lower CFC concentrations (Figure 3a), suggesting that this lighter AABW flows over an older bottom layer. Our results indicate that, whereas in the $1990 \mathrm{~s}$, this bottom water had no distinct thermohaline signal, in the $2000 \mathrm{~s}$, it had a clear $\theta-S$ signature not documented previously (Figures $2 \mathrm{c}$ and $2 \mathrm{~d}$ ). Figures $3 \mathrm{~b}$ and $3 \mathrm{c}$ reveal a translation in the $\mathrm{CFC}-\theta$ profile but not in CFC-S: the CFC maximum shifts from approximately $\theta=-0.5^{\circ} \mathrm{C}$ in the 1990 s to $\theta=-0.4^{\circ} \mathrm{C}$ in 2008 . Therefore, the $0.02-0.03 \mathrm{~kg} \mathrm{~m}^{-3} \mathrm{AABW}$ lightening is induced by a $0.1^{\circ} \mathrm{C}$ change in temperature rather than salinity.

\section{Discussion}

[9] The deep CFC maximum observed in AABW near the continental slope at $30^{\circ} \mathrm{E}$ suggests recent ventilation in the region of Prydz Bay [e.g., Jacobs and Georgi, 1977; Archambeau et al., 1998]. Indeed, the nearby Cape Darnley polynya $\left(69^{\circ} \mathrm{E}\right)$ was recently shown to be a significant source of new bottom water, contributing $13 \%-30 \%$ of Atlantic sector AABW production, although the role of the Amery Ice Shelf could not be dismissed [Ohshima et al., 2013]. The CFC-11 and CFC- 12 concentrations observed at $30^{\circ} \mathrm{E}$ between 1993 and 2008 (Figure 3, CFC-12 not shown) within the Indian sector-sourced AABW indicate transit times of 6-9 years, although $\theta-S$ anomalies can propagate more rapidly [Waugh and Hall, 2005]. These divergent estimates are probably due to differing atmospheric histories. Using the Cape Darnley area as the ventilation source, the transit time implies velocities in reasonable agreement with near-bottom velocities observed along the shelf break between Prydz Bay and $30^{\circ} \mathrm{E}\left(\sim 0.05 \mathrm{~ms}^{-1}\right)$ [Meijers et al., 2010], indicating minimal influence of AABW varieties from other sources.

[10] Our observations suggest that a warming, rather than a freshening, of the Indian sector-sourced AABW is the dominant cause of its lightening. This warming could be caused by changes in: (1) source region shelf water properties; (2) the flux of heat to cascading shelf water plumes via a change in the temperature and/or rate of entrainment of relatively warm, mid-depth Circumpolar Deep Water (CDW); or (3) the rates of advection or mixing of the newly formed $\mathrm{AABW}$ during its transit between the deep ocean off Cape Darnley and $30^{\circ}$ E. Cause (1) seems unlikely as shelf waters must reach the freezing point to undergo sea ice formation and dense water production.

[11] CDW warming at the continental slope off Cape Darnley could be caused by either a warming within the 
a)
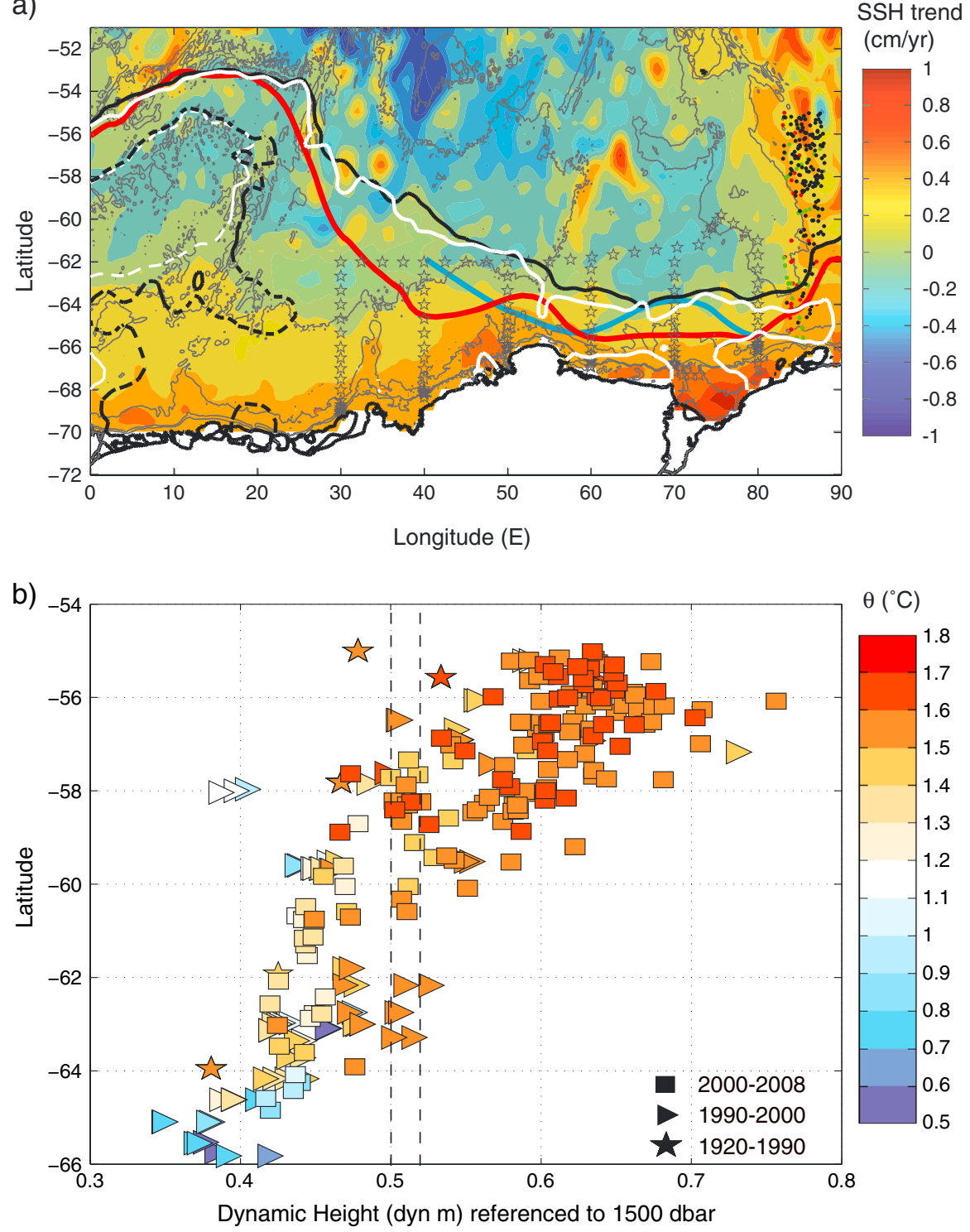

Figure 4. (a) (color shading) Map of SSH linear trend in the eastern Weddell gyre, 1996-2008 $\left(\mathrm{cm} \mathrm{yr}^{-1}\right)$. Red line: climatological ACC Southern Boundary (SBdy) position defined from hydrography [Orsi et al., 1995]. Light blue line: SBdy during the (stars) 2006 BROKE-West cruise. Black and white lines: mean SBdy SSH contour [Sokolov and Rintoul, 2009] in 1996 and 2008, respectively. Dashed black and white lines: mean SSH contour of the Weddell gyre in 1995 and 2007, respectively. Dots depict CTD and Argo profiles; red (1920-1990), green (1990-2000) and black (2000-2008). (b) Dynamic height (dyn $\mathrm{m}$ ) versus latitude and $\theta$ (colors, ${ }^{\circ} \mathrm{C}$ ) of the $\mathrm{CDW}$ salinity maximum of profiles collected in the Prydz Bay region. Vertical dashed lines: dynamic height associated with the SBdy [Sokolov and Rintoul, 2009]. Symbols denote profile eras; squares: Argo-era (2000 to 2008), triangles: 1990-2000, stars: 1920-1990.

ACC [e.g., Gille, 2002] or by a southward migration of the ACC's Southern Boundary (SBdy) [Orsi et al., 1995] in response to changes in atmospheric forcing [Sallée et al., 2008]. To investigate the former hypothesis, the $\theta$ of the CDW core (defined as a mid-depth $S$ maximum) is mapped onto dynamic height referenced to $1500 \mathrm{dbar}$ for three periods (Figure $4 \mathrm{~b}$ ). The region closest to Cape Darnley with sufficient data coverage $\left(80^{\circ} \mathrm{E}-90^{\circ} \mathrm{E}\right)$ was selected here. South of the SBdy (defined as a dynamic height of $0.51 \pm 0.01 \mathrm{~m}$ referenced to $1500 \mathrm{dbar}$, black dashed lines) [Sokolov and Rintoul, 2009], no significant warming of the CDW in baroclinic streamfunction space is found (i.e., for a given dynamic height, the most recent $\theta$ is not systematically higher than for earlier periods), although the region's data paucity makes this difficult to state definitively.

[12] Instead, an indication of a southward SBdy translation is found in altimetric and hydrographic observations. Eastern Weddell gyre $\mathrm{SSH}\left(55^{\circ} \mathrm{S}-65^{\circ} \mathrm{S}, 30^{\circ} \mathrm{E}-90^{\circ} \mathrm{E}\right)$ exhibits a linear trend of $2.8 \pm 0.6 \mathrm{~mm} \mathrm{yr}^{-1}$ between 1996 and 2008; a total local sea level rise of $3.4 \pm 0.48 \mathrm{~cm}$ over this period (Figure 4a). This suggests that the regional SBdy has migrated southward by around 100-200 km. Comparisons of the hydrographic SBdy positions in 1995 and 2006 (Figure 4a, red and light blue lines) with their altimetrically derived counterparts in 1996 and 2008 (white and black lines) reveal good agreement between the two techniques, 
supporting the use of altimetry to track the SBdy's movement. Given a climatological meridional gradient in the CDW core $\theta$ of $\sim 0.2^{\circ} \mathrm{C} / 100 \mathrm{~km}$ north of the Prydz Bay region (Figure 4b), the SBdy's observed southward translation implies a $\mathrm{CDW}$ core warming of $0.2^{\circ} \mathrm{C}-0.4^{\circ} \mathrm{C}$ near the continental slope. This compares favorably with the observed AABW warming of $\sim 0.1^{\circ} \mathrm{C}$, assuming a $\sim 60 \% \mathrm{CDW}$ component in the newly formed AABW [Foster and Carmack, 1976].

[13] A potentially pertinent feature of the regional circulation change between the mid-1990s and the late 2000s is the concurrent westward retreat of the Weddell gyre (Figure 4a), which may have facilitated the Indian sector-sourced AABW's penetration into the gyre's east. However, mean water mass ages calculated for the AABW CFC maximum using the TTD method [Waugh et al., 2004] with constant parameters (ventilated fraction CFC-12 saturation of $60 \%, \Delta /-\Gamma=1)$ indicate a greater-than-expected ageing ( $\sim 25$ years) between 1993 and 2008 (not shown), consistent with accompanying increases in apparent oxygen utilization. This is compatible with an increased rate of CDW entrainment.

[14] A possible issue with this explanation is that a southward SBdy shift should also increase the salinity of CDW entrained into the $\mathrm{AABW}$ layer. We estimate that the $\mathrm{CDW}$ salinity increase near the shelf break corresponding to a $0.2^{\circ} \mathrm{C}-0.4^{\circ} \mathrm{C}$ warming should be $0.01-0.03$. This would accompany a $0.007-0.021$ AABW salinity increase not observed at $30^{\circ} \mathrm{E}$ (Figure $3 \mathrm{c}$ ). The reasons for this are unclear, yet a plausible conjecture is that the freshening of dense shelf waters upstream of the Amery region [e.g., Jacobs and Giulivi, 2010] may propagate westward by Antarctic slope flows and offset an increase in AABW salinity incurred by local entrainment of more saline CDW. A freshening trend of 0.003 year $^{-1}$ since the late 1950 s near the Ross Ice shelf has been linked to concurrent AABW freshening (by $\sim 0.01$ between 1993 and 2003/2004) as far west as $\sim 85^{\circ} \mathrm{E}$, immediately east of the Amery region [Jacobs and Giulivi, 2010].

\section{Conclusions}

[15] This study documents a decadal scale warming (by $0.1^{\circ} \mathrm{C}$ ) and lightening (by $0.02-0.03 \mathrm{~kg} \mathrm{~m}^{-3}$ ) of the $\mathrm{AABW}$ entering the eastern Weddell gyre from the Indian sector, between the mid-1990s and late 2000s. These changes add to recent findings of decadal scale variations in AABW $\theta-S$ characteristics, which describe either freshening [Aoki et al., 2005; Rintoul, 2007; Jacobs and Giulivi, 2010] or warming linked to variable wind-forced bottom water export [Meredith et al., 2008, 2011; Jullion et al., 2010]. Our work attributes the observed AABW warming to a new mechanism: a change in the entrainment of warm, mid-depth waters into cascading shelf water plumes. This shifts the resultant bottom water mixture to a warmer and lighter class, consistent with the observed contraction of the coldest AABW [Purkey and Johnson, 2010, 2012]. This process most plausibly explains our measured AABW property changes and is concomitant with the poleward SBdy shift in the Prydz Bay region observed between 1996 and 2008. Insofar as the SBdy's southward migration off Cape Darnley is part of a recent, large-scale adjustment of the ACC to climatic changes in wind forcing [Sallée et al., 2008; Sokolov and Rintoul, 2009], we conjecture that the induction of AABW warming by changes in CDW entrainment may affect the formation area near the Adélie Land coast and wherever the ACC flows close to the Antarctic continental shelf. Fahrbach et al. [2011] explain how wind-forced ACC translations affect the properties of CDW entering the Weddell gyre, which then influences the AABW formed. Therefore, such ACC shifts as the one we describe could also indirectly affect AABW produced in the Ross and Weddell gyres.

[16] Acknowledgments. We thank both reviewers for their helpful comments, the crews and science teams whose work has made this study possible, particularly Rana Fine, Sabrina Speich and Jim Happell for the I6S 2008 CFC data, NERC grant NE/E01366X/1 and NSF Grants OCE-0927583 and OCE-0622670 for financial support.

[17] The editor would like to acknowledge the work of two anonymous reviewers who contributed to the manuscript.

\section{References}

Aoki, S., S. R. Rintoul, S. Ushio, S. Watanabe, and N. L. Bindoff (2005), Freshening of the Adélie Land Bottom Water near $140^{\circ} \mathrm{E}$, Geophys. Res. Lett., 32, L23601, doi:10.1029/2005GL024246.

Archambeau, A.-S., C. Pierre, A. Poisson, and B. Schauer (1998), Distributions of oxygen and carbon stable isotopes and CFC-12 in the water masses of the Southern Ocean at $30^{\circ} \mathrm{E}$ from South Africa to Antarctica: Results of the CIVA1 cruise, J. Marine Syst., 17, 25-38.

Fahrbach, E., M. Hoppema, G. Rohardt, O. Boebel, O. Klatt, and A. Wisotzki (2011), Warming of deep and abyssal water masses along the Greenwich meridian on decadal time scales: the Weddell Gyre as a heat buffer, Deep Sea Res. II, 58, 2509-2523, doi:10.1016/j. dsr2.2011.06.007.

Foster, T., and E. Carmack (1976), Frontal zone mixing and Antarctic Bottom Water formation in the southern Weddell Sea, Deep Sea Res., 23(4), 301-317.

Ganachaud, A., and C. Wunsch (2000), Improved estimates of global ocean circulation, heat transport and mixing from hydrographic data, Nature, 408, 453-457.

Gille, S. T. (2002), Warming of the Southern Ocean since the 1950s, Science, 295, 1275-1277, doi:10.1126/science.1065863.

Jacobs, S. S., and D. T. Georgi (1977), Observations on the Southwest Indian/Antarctic Ocean, in A Voyage of Discovery, edited by M. Angel, pp. 43-84, Pergamon, New York.

Jacobs, S. S., and C. F. Giulivi (2010), Large multidecadal salinity trends near the Pacific-Antarctic continental margin, J. Clim., 23, 4508-4524, doi:10.1175/2010JCLI3284.1.

Jacobs, S. S., C. F. Giulivi, and P. A. Mele (2002), Freshening of the Ross Sea during the late 20th Century, Science, 297, 386-389, doi:10.1126/ science. 1069574.

Jullion, L., S. C. Jones, A. C. Naveira Garabato, and M. P. Meredith (2010), Wind-controlled export of Antarctic Bottom Water from the Weddell Sea, Geophys. Res. Lett., 37, L09609, doi:10.1029/2010GL042822.

Klatt, O., W. Roether, M. Hoppema, K. Bulsiewicz, U. Fleischmann, C. Rodehacke, E. Fahrbach, R. F. Weiss, and J. L. Bullister (2002), Repeated CFC sections at the Greenwich Meridian in the Weddell Sea, J. Geophys. Res., 107(C4), doi:10.1029/2000JC000731.

Le Traon, P. Y., F. Nadal, and N. Ducet (1998), An improved mapping method of multisatellite altimeter data, J. Atmos. Ocean. Tech., 15, 522-534.

Meijers, A. J. S., A. Klocker, N. L. Bindoff, G. D. Williams, and S. J. Marsland (2010), The circulation and water masses of the Antarctic shelf and continental slope between 30 and $80^{\circ}$ E, Deep Sea Res. II., 57, 723-737, doi:10.1016/j.dsr2.2009.04.019.

Meredith, M. P., A. C. Naveira Garabato, A. L. Gordon, and G. C. Johnson (2008), Evolution of the Deep and Bottom Waters of the Scotia Sea, Southern Ocean, during 1995-2005, J. Clim., 21(13), 3327-3343.

Meredith, M. P., A. L. Gordon, A. C. Naveira Garabato, E. P. Abrahamsen, B. A. Huber, L. Jullion, and H. J. Venables (2011), Synchronous intensification and warming of Antarctic Bottom Water outflow from the Weddell Gyre, Geophys. Res. Lett., 38, L03603, doi:10.1029/ 2010GL046265.

Ohshima, K. I., et al. (2013), Antarctic Bottom Water production by intense sea-ice formation in the Cape Darnley Polynya, Nat. Geosci., 6, 235-240, doi:10.1038/ngeo 1738 .

Orsi, A. H., T. Whitworth III, and W. D. Nowlin Jr. (1995), On the meridional extent and fronts of the Antarctic Circumpolar Current, Deep Sea Res. I, 42(5), 641-673.

Orsi, A. H., G. C. Johnson, and J. L. Bullister (1999), Circulation, mixing, and production of Antarctic Bottom Water, Prog. Oceanogr., 43(1), 55-109. 


\section{COULDREY ET AL.: AABW WARMING IN THE EASTERN WEDDELL GYRE}

Pritchard, H. D., S. R. M. Ligtenberg, H. A. Fricker, D. G. Vaughan, M. R. van den Broeke, and L. Padman (2012), Antarctic ice-sheet loss driven by basal melting of ice shelves, Nature, 484, 502-505, doi:10.1038/nature10968.

Purkey, S. G., and G. C. Johnson (2010), Antarctic Bottom Water warming between the 1990s and the 2000s: Contributions to global heat and sea level rise budgets, J. Clim., doi:10.1175/2010JCLI3682.1.

Purkey, S. G., and G. C. Johnson (2012), Global contraction of Antarctic Bottom Water between the 1980s and 2000s, J. Clim., 25, 5830-5844, doi:10.1175/JCLI-D-11-00612.1.

Rintoul, S. R. (2007), Rapid freshening of Antarctic Bottom Water formed in the Indian and Pacific oceans, Geophys. Res. Lett., 34, L06606, doi:10.1029/2006GL028550.
Sallée, J. B., K. Speer, and R. Morrow (2008), Southern Ocean fronts and their variability to climate modes, J. Clim., 21(12), 3020-3039.

Sokolov, S., and S. R. Rintoul (2009), Circumpolar structure and distribution of the Antarctic Circumpolar Current fronts: 1. Mean circumpolar paths, $J$. Geophys. Res., 114, C11018, doi:10.1029/2008JC005108.

Waugh, D. W., and T. M. Hall (2005), Propagation of tracer signals in boundary currents, J. Phys. Oceanogr., 35, 1538-1552, doi:10.1175/ JPO2779.1.

Waugh, D. W., T. M. Hall, and T. W. N. Haine (2003), Relationships among tracer ages, J. Geophys. Res., 108(C5), doi:10.1029/2002JC001325.

Waugh, D. W., T. W. N. Haine, and T. M. Hall (2004), Transport times and anthropogenic carbon in the subpolar North Atlantic Ocean, Deep Sea Res. I, 51, 1475-1491, doi:10.1016/j.dsr.2004.06.011. 